PRACE GEOGRAFICZNE

zeszyt 162, 2020, 125-144

doi: 10.4467/20833113PG.20.015.13102

Instytut Geografii i Gospodarki Przestrzennej UJ

Komisja Geograficzna, Polska Akademia Umiejętności

Wydawnictwo Uniwersytetu Jagiellońskiego

\title{
ZAGOSPODAROWANIE PRZESTRZENI KAMPUSU UNIWERSYTECKIEGO Z PERSPEKTYWY STUDENTÓW
}

Agnieszka Konior, Weronika Pokojska

\section{Spatial management of a university campus from students' perspective}

\begin{abstract}
The article concerns one of the basic groups of stakeholders on university campuses: students. Theoretical issues related to planning of public spaces, including university campuses, will be discussed, with particular emphasis on socializing the planning process and organization of socio-cultural events. The results of research conducted among students of culture and media management (Institute of Culture of the Jagiellonian University) will be presented. The research was conducted as part of the subject Urban projects (formerly Project management in urban space) in 2017/2018-2019/2020. The students' task was to develop an analysis of the Jagiellonian University campus space, with particular emphasis on the building of the Faculty of Management and Social Communication (in which they defined their strengths, weaknesses, opportunities and threats), defined the target group, and proposed actions that could improve the quality of public spaces on the Jagiellonian University Campus (implemented with low/high expenditure in the short/long term). The work was carried out in groups, in total more than 60 responses were collected. 'Good practices' in the field of socio-cultural student activities that liven up campus space (e.g. the Culture and Media Festival Polikultura in Krakow) will also be presented.
\end{abstract}

Keywords: university campuses, public space, stakeholder, space planning, Jagiellonian University 
Zarys treści: Artykuł dotyczy jednej z podstawowych grup interesariuszy kampusów uniwersyteckich, a więc studentów. Omówione zostaną zagadnienia teoretyczne związane z planowaniem przestrzeni publicznych, w tym kampusów uniwersyteckich, ze szczególnym akcentem na uspołecznienie procesu planowania i organizacje wydarzeń spoleczno-kulturalnych. Przedstawione będą wyniki badań p Zarządzanie kulturą i mediami (Instytut Kultury UJ). Badania prowadzone były w ramach przedmiotu Projekty miejskie (wcześniej Zarządzanie projektami w przestrzeni miejskiej) w latach 2017/2018-2019/2020. Zadaniem studentów było dokonanie analizy przestrzen kampusu UJ, ze szczególnym uwzględnieniem samego budynku Wydziału Zarządzania i Komunikacji Społecznej UJ (w której ramach określili ich silne i słabe strony, szanse i zagrożenia) zdefiniowanie orupy docelowej przestrzeni oraz zaproponowanie działán, które moghy podnieść jakość przestrzeni publicznych Kampusu UJ (realizowanych małym/dużym nakładem środków w krótkiej/długiej perspektywie czasowej). Praca była realizowana w grupach, łącznie zebrano ponad 60 odpowiedzi. Ponadto zaprezentowane zostaną „dobre praktyki” z zakresu studenckich działań społeczno-kulturalnych, które wpływają na ożywienie przestrzeni kampusów (np. Festiwal Kultury i Mediów „Polikultura” w Krakowie).

Stowa kluczowe: kampusy uniwersyteckie, przestrzeń publiczna, interesariusze, zagospodarowanie przestrzeni, Uniwersytet Jagielloński

\section{Wstęp}

Kampus to w powszechnym rozumieniu kompleks budynków należących do danej organizacji, zwykle jednostki szkolnictwa wyższego - szkoły wyższej czy uniwersytetu. Najczęściej w obrębie jego granic znajdują się budynki wydziałów, aule, pomieszczenia administracyjne, laboratoria, akademiki, stołówki, infrastruktura sportowa i rekreacyjna itd. Kampus w takim rozumieniu jest nie tylko miejscem pracy i edukacji, lecz także przestrzenią, w której społeczność akademicka spędza dużą część swojego życia. Projekt przestrzeni dydaktycznej i naukowej powinien więc odznaczać się funkcjonalnością, a także możliwością adaptacji do potrzeb uczeln (Rymarzak 2014). Niezależnie od zmieniającego się stylu życia, postępującej digitalizacji i technologizacji fizyczna przestrzeń kampusu pozostaje miejscem wymiany myśli, inkubatorem rozwoju nauki (zob. Cannas da Silva, Valsassina Heitor 2017). W związku z tym, że otoczenie potrafi determinować zarówno samopoczucie, jak i efektywność, kreatywność ludzi, szczególnie przestrzenie kampusów powinny temu sprzyjać dzięki swojej strukturze i estetyce. Za Eelis Rytkönen (2014) można wskazać, że misję współczesnych uniwersytetów stanowią: edukacja, badania i oddziaływanie na społeczeństwo. Infrastruktura kampusów powinna holistycznie wspierać realizację tych celów, przy czym badaczka wskazuje, że przestrzeń kampusów musi być tak zaprojektowana, by umożliwiała tworzenie wspólnoty uniwersyteckiej.

Jak pisze Ozan Ağlargöz (2017), przestrzeń organizacyjną (jaka jest też kampus) można rozpatrywać na różne sposoby: jako fizyczną odległość między punktami; jako przeżywane doświadczenie (lived experience), w którym kluczową rolę odgrywają symbolika, estetyka, interpretacja; jako zmaterializowane relacje władzy (materialized power relations). Niezależnie od przyjętej perspektywy badacze zdają się zgodni co do tego, że otoczenie znacząco wpływa na interakcje, indywidualne i grupowe zachowania

Ponadto przestrzeń fizyczna organizacji jest wyrazem jej wartości, misji i kultury organizacyjnej (Cannas da Silva, Valsassina Heitor 2017). Mówi o tym model Edgara Scheina, w którym wyróżnia się trzy poziomy charakterystycznych dla kultury organizacyjnej elementów. Podstawowe dla niej są niewidoczne na co dzień i zwykle nieuświadomione założenia podstawowe, z których wynikają normy i wartości (Zbiegień-Maciąg 1999 za: Mazur 2014). Ich przejawem są z kolei artefakty: językowe, behawioralne i fizyczne w postaci „namacalnych tworów danej kultury” (Mazur 2014). Do tej ostatniej grupy należy zaliczyć kampusy uniwersyteckie.

Jak pisze Małgorzata Rymarzak (2016: 236), budynki należące do uczelni mają wiele funkcji do spełnienia: „[...] nieruchomości warunkują realizację procesów dydaktycznych i prowadzonych badań naukowych, a w konsekwencji możliwośc rozwojowe i budowanie zamierzonej pozycji oraz przewagi konkurencyjnej uczelni. Ich stan wpływa m.in. na jakość świadczonych usług edukacyjnych, wizerunek uczelni w otoczeniu oraz może determinować decyzje studentów i pracowników o wyborze uczelni jako miejsca nauki czy pracy".

Luísa Cannas da Silva i Teresa Valsassina Heitor (2017) opisują różne typy „morfologii uniwersytetów”, pokazujące zależność między uniwersytetem (kampusem) a miastem, w którym się znajduje. W analizowanych typach brane są pod uwagę takie czynniki, jak autonomiczność przestrzeni i zintegrowanie z miastem. III Kampus Uniwersytetu Jagiellońskiego (UJ) znajdujący się na obszarze Krakowa zwanym Ruczajem, będący przedmiotem niniejszej analizy, zdaje się ciekawym przykładem nie do końca przystającym do „czystych” typów zaproponowanych przez autorów. $Z$ punktu widzenia lokalizacji może być „kampusem graniczącym z miastem" (campus edging the city) lub znajdującym się w mieście, choć peryferyjnośc Ruczaju skłania jednak do zaakcentowania „pogranicza” w stosunku do centralnych dzielnic Krakowa. Problematyczne zdaje się również określenie stopnia autonomil: w chwili obecnej kampus stanowi w zasadzie jedynie przestrzeń naukową, edukacyjną, z ograniczonym spektrum miejsc o innych funkcjach. Wynika to przede wszystkim $\mathrm{z}$ tego, że jest przestrzenią w pewnym sensie wciąż powstającą. $\mathrm{O}$ ile budynki wydziałów istnieją już częściowo od dekady, o tyle pozostała infrastruktura dopiero jest w trakcie realizacji.

Rozpatrując przestrzenie kampusów jako szczególny rodzaj przestrzeni publicznej, należy założyć, że obowiązują w ich kształtowaniu te same zasady. W kontekście niniejszego tekstu najważniejsze zdaje się dostrzeżenie potrzeb użytkowników przestrzeni - zgodnie z zasadą „społeczność jest ekspertem”: „[...] Ludzie mają szerokie spojrzenie i wartościowy wgląd w to, jak funkcjonuje obszar, po którym się 
na co dzień poruszają; mają niezrównane rozeznanie w sprawach, które są ważne. Im wcześniej społeczność zostanie włączona w proces planowania, tym lepiej-najlepiej przed rozpoczęciem całego procesu. Ludzie powinni być zachęcani i ośmielani do angażowania się w przekształcanie przestrzeni, aby stali się właścicielami oraz opiekunami miejsc w czasie ich przeobrażeń (Jak præetworzyć miejsce?...)”.

\section{Metodologia}

Celem niniejszego artykułu jest wskazanie czynników, które w opinii studentów mogłyby przyczynić się do poprawy funkcjonalności III Kampusu UJ, oraz przedstawienie dobrych praktyk w obszarach wskazanych przez studentów jako wymagające poprawy. Na część empiryczną artykułu składają się: analiza wyników przygotowanej przez studentów listy czynników wewnętrznych i zewnętrznych, które w dalszej perspektywie mogą posłużyć do stworzenia pełnej analizy SWOT dotyczącej przestrzeni III Kampusu UJ, oraz zaproponowane przez nich działania mogące poprawic jakość przestrzeni kampusu w bliższej i dalszej perspektywie. Przykłady dobrych praktyk związanych ze społeczno-kulturalną aktywnością studentów na terenach kampusów uniwersyteckich, które zostały przeanalizowane metodą studium przypadku, są zaprezentowane w dalszej części tekstu. Mają one stanowić odpowiedź na zapotrzebowania wskazywane przez studentów i być inspiracją do dalszych działań wskazując, jakie przedsięwzięcia podejmowane są na innych kampusach uniwersyteckich i przynoszą zamierzone rezultaty.

Analiza SWOT należy do podstawowych metod wykorzystywanych w zarządzaniu strategicznym. Jej nazwa jest akronimem angielskich słów: Strenghts (mocne strony) Weaknesses (słabe strony), Opportunities (szanse), Threats (zagrożenia). Analiza SWOT polega na diagnozie obecnej sytuacji i stworzeniu wizji przyszłości. Silne i słabe strony są umiejscowione wewnątrz jednostki i mają wpływ na budowanie przez nią przewagi konkurencyjnej (lub jej brak), natomiast szanse i zagrożenia stanowią zbiór czynników zewnętrznych, a reakcja na nie może stanowić impuls do rozwoju jednostk lub stać się jego barierą (Koźmiński, Piotrowski 2006). Początkowo analiza SWOT była wykorzystywana w przedsiębiorstwach komercyjnych, dziś jest powszechnie używana jako narzędzie w procesach planistycznych, np. w trakcie warsztatów partycypacyjnych w ramach rewitalizacji obszarów (zob. Boryczka i in. 2018).

Analiza zaprezentowana w niniejszym artykule prowadzona była w ramach przedmiotu Projekty miejskie (wcześniej Zarządzanie projektami w przestrzeni miejskiej) w latach 2017/2018-2019/2020 w Instytucie Kultury UJ (kierunki: Zarządzanie kulturą i mediami, Zarządzanie kulturą współczesną, Zarządzanie mediami i reklamą), na studiach stacjonarnych i niestacjonarnych ${ }^{1}$. Zadaniem studentów było opracowanie wstępnej listy czynników stanowiących silne i słabe strony oraz szanse i zagrożenia dla przestrzeni III Kampusu Uniwersytetu Jagiellońskiego, ze szczególnym uwzględnieniem samego budynku Wydziału Zarządzania i Komunikacji Społeczne (WZiKS) UJ. Mieli oni również zdefiniować grupę docelową przestrzeni kampusu oraz zaproponować działania realizowane małym i dużym nakładem środków w krótkiej i długiej perspektywie czasowej, które mogłyby podnieść jakość przestrzeni III Kampusu UJ. Praca była wykonywana w grupach o różnej liczebności (ok. 4-5 osób). Łącznie zebrano odpowiedzi od 64 grup studenckich. Odpowiedzi udzielane przez studentów zostały zakodowane, liczby na wykresach odnoszą się do liczby wskazań. W opisach zawarto również informację na temat odpowiedzi, które padały rzadziej (na wykresach wskazano te, które wymieniło 10 i więcej grup) Wyniki badań nie mogą być generalizowane na ogół społeczności akademickiejpróba, chociaż znaczna liczbowo, nie jest reprezentatywna, bo dotyczy tylko studentów jednego instytutu. Jednakże dane pozyskane w ten sposób mogą być analizowane jakościowo i dają wgląd w to, jak młodzi ludzie oceniają przestrzeń Kampusu UJ, co z punktu widzenia osób zarządzających tą przestrzenią stanowi bardzo istotny zbiór informacji i może stać się podstawą do stworzenia analizy SWOT.

\section{Analiza przestrzeni III Kampusu UJ}

Koncepcje budowy kampusu dla Uniwersytetu Jagiellońskiego pojawiły się już w latach 70. XX w., ale intensyfikacja działań nastąpiła na przełomie XX i XXI w., stąd też pełna nazwa: Kampus 600-lecia Odnowienia Uniwersytetu Jagiellońskiego w 2000 r. przypadała rocznica 600-lecia odnowienia uniwersytetu przez Władysława Jagiełłę zgodnie z zapisem testamentowym królowej Jadwigi.

Pierwszym budynkiem, który powstał na terenie Kampusu UJ, było Centrum Badań Przyrodniczych, którego budowę zakończono w 2000 r. Stopniowo na terenie dzielnicy Dębniki (popularna nazwa okolicy to Ruczaj, od pobliskiego osiedla Ruczaj-Zaborze) powstawały kolejne budynki, np. Instytut Nauk o Środowisku, Instytut Geografii i Gospodarki Przestrzennej, Wydział Matematyki i Informatyki, Instytut Zoologii, Małopolskie Centrum Biotechnologii czy Wydział Chemii. W 2009 r. do użytku został oddany budynek Wydziału Zarządzania i Komunikacji Społeczne

Wyniki badań w pierwotnym zamyśle służyły jedynie pracy na zajęciach oraz ewentualnemu przekazaniu władzom, np. dziekanom; pierwotnym zamiarem nie było wykorzystanie ich do celów naukowych. Jednakże cel praktyczny naszych badań (czyli poprawa jakości przestrzeni Kampusu UJ) zdaje się uzasadniać wykorzystanie wyników analizy w taki sposób. Ze względu na brak bezpośredniej zgody rzystanie wyniḱw ich pracy w niniejszym artykule będą jedynie przytaczane ich wypowiedzi, bez cytowania. 
UJ. Był to jeden z pięciu pierwszych budynków na Kampusie UJ. Budynki łączy szeroki deptak - aleja Wawelska, z której końca widać Wzgórze Wawelskie, pomiędzy budynkami znajduje się starannie zaplanowana zieleń. W 2012 r. otwarto linię tramwajową biegnącą wzdłuż Kampusu UJ (Powstanie Kampusu...).

\section{Mocne strony Kampusu UJ i budynku WZiKS}

Analizując mocne strony Kampusu UJ (ryc. 1), studenci docenili przede wszystkim otaczającą go, zadbaną zieleń oraz jego dostępność komunikacyjną² (dogodne połączenia autobusowe i tramwajowe, usytuowanie blisko autostrady). Uznanie studentów zdobyła nowoczesna architektura poszczególnych budynków oraz ich wizualna spójność. Pozytywnie oceniono również obecność dużych i bezpłatnych parkingów samochodowych przy każdym z wydziałów, siłowni zewnętrznej oraz ścieżek pieszych (chodniki i aleje z zakazem wjazdu samochodów). Umiejscowienie punktów gastronomicznych na każdym wydziale, takich jak stołówki i kawiarnie, także zostało uznane za mocną stronę. Zwracano uwagę, że III Kampus to duża przestrzeń, na której skoncentrowanych jest kilkanaście wydziałów, co sprzyja integracji studentów, ułatwia przemieszczanie się między instytutami i wydziałami oraz studiowanie kilku kierunków jednocześnie.

Studenci wskazywali ponadto na wyposażenie sal w nowoczesną infrastrukturę: w budynkach mieszczą się laboratoria, studio telewizyjne i radiowe, a sale dydaktyczne posiadają odpowiednie osprzętowanie. Około 1/3 grup zwróciła uwage na dużą liczbę ławek, które znajdują się w przestrzeni publicznej (wyróżniono je jako osobny element małej architektury, w skład której weszły: mapy, kosze na śmieci, fontanny, popielniczki czy obiekty artystyczne). Zdaniem studentów mocną stroną III Kampusu UJ są także liczne udogodnienia dla rowerzystów, takie jak: ścieżki, stojaki, wiaty czy (nieistniejące już) wypożyczalnie rowerów Wavelo. Doceniono również bliskość sklepu wielkopowierzchniowego. Wydział Zarządzania i Komunikacji Społecznej, zdaniem części studentów, jest dobrze dostosowany do potrzeb osób z niepełnosprawnościami.

Nieco mniejsza liczba wskazań dotyczyła punktów usługowych znajdujących się zarówno wewnątrz budynku Wydziału (ksero, szatnie, punkt sprzedaży obwarzanków czy bezobsługowe automaty), jak i na zewnątrz (np. bank, przychodnia zdrowia, kawiarnia). Wskazano również, że budynki są przestronne z przeszklonymi oknami

Trudno rozstrzygnąć, czy dostępność komunikacyjna III Kampusu UJ jest mocną stroną czy szansą dpowiedzialne za powstanie infrastruktury komunikacyjnej były władze lokalne i regionalne, jednakż władze UJ mogły mieć wpływ na wybór lokalizacji Kampusu czy lobbować na rzecz wzmocnienia transportu publicznego w tym rejonie. Ostatecznie autorki pracy zdecydowały się na pozostawienie tej cechy zację, zarówno wśród mocnych, jak i słabych stron - wskazując, że można je oceniać z różnych perspektyw. mogą pomieścić dużo osób. Przestrzeń III Kampusu UJ, zdaniem studentów, jes estetyczna, spokojna i przyjazna, mocną stronę stanowi także sąsiedztwo zalewu Zakrzówek. Dziesięć grup wskazało, że budynek usytuowany jest w dogodnej lokalizacji; najczęściej w tym kontekście wymieniali oni bliskość dużych osiedl mieszkaniowych. Inne mocne strony, które zyskały mniejszą liczbę wskazań, to utrzymanie przestrzeni w czystości i poczucie bezpieczeństwa; budynki zdaniem części studentów były dobrze rozplanowane, wszystkie zajęcia odbywały się w jednym miejscu, znaczenie miała także marka Uniwersytetu Jagiellońskiego. Wskazano również na obecność takich udogodnień, jak biblioteka, wi-fi czy windy. Tylko cztery grupy zaznaczyły, że mocną stroną III Kampusu UJ i budynku WZiKS jest obecność przestrzeni specjalnie przeznaczonej dla studentów - do nauki i wypoczynku.

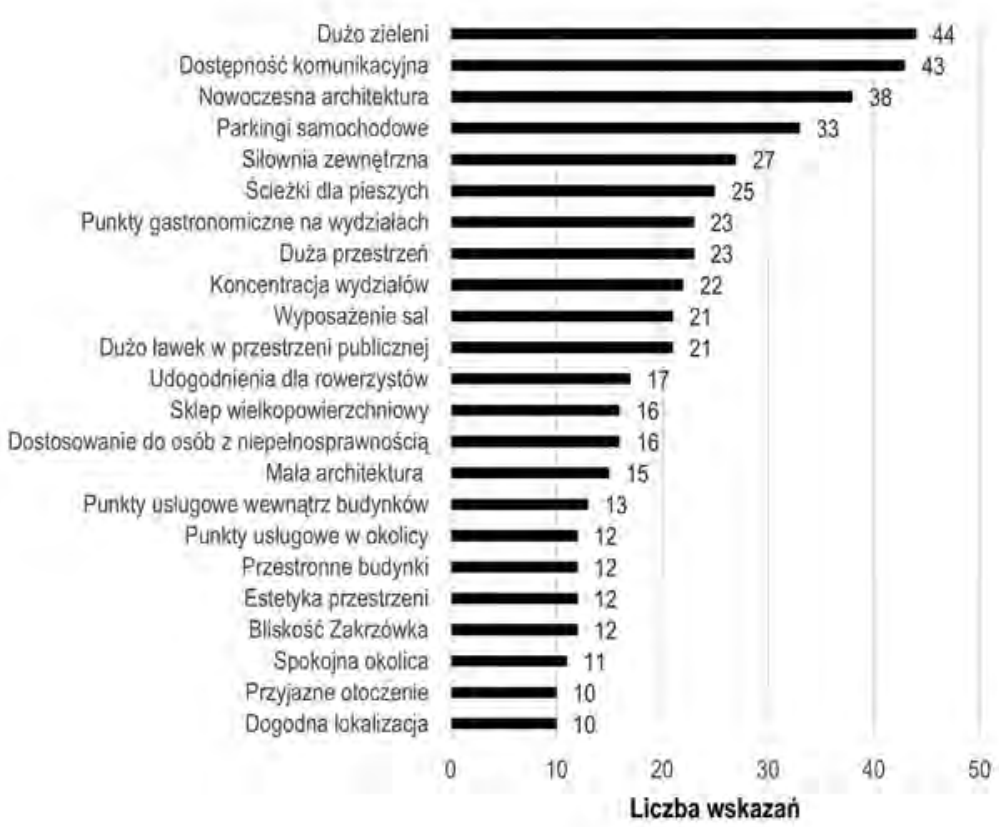

Ryc. 1. Mocne strony Kampusu UJ i budynku WZiKS

Fig. 1. Strenghts of the JU (Jagiellonian University) Campus and the FoMaSK (Faculty of Management and Social Communication) building 


\section{Słabe strony III Kampusu UJ i budynku WZiKS}

Najczęściej wymienianą słabą stroną Kampusu UJ (ryc. 2) była odległa lokalizacja znajduje się on daleko od centrum Krakowa. Studenci wskazywali również na małą liczbę stołówek, ich niewielką pojemność oraz niezróżnicowaną ofertę posiłków, które bywają niskiej jakości. Ponadto na Kampusie brakuje miejsc służących integracji i rozrywce, takich jak kluby studenckie, restauracje czy kawiarnie. Studenc mogliby tam spędzać swój wolny czas, zamiast wracać do mieszkań w przerwach między zajęciami. Ich zdaniem mogłaby to także być przestrzeń, w której ćwiczyliby swoje umiejętności związane z organizacją wydarzeń kulturalnych (np. koncerty, wystawy, spektakle teatralne). Zdaniem części studentów cały kompleks został źle zaplanowany - poruszanie się po wnętrzach budynków nie jest intuicyjne, nie ma np. bezpośredniego dojścia do siłowni na świeżym powietrzu, do niektórych budynków najcześciej wchodzi się przez wejścia boczne, a ponadto budynk i sale nie są dostatecznie oznakowane. Wskazywano także, iż słabą stroną jest brak infrastruktury sportowej (hala, basen, stadion, siłownia) oraz zbyt mała ilość zieleni,

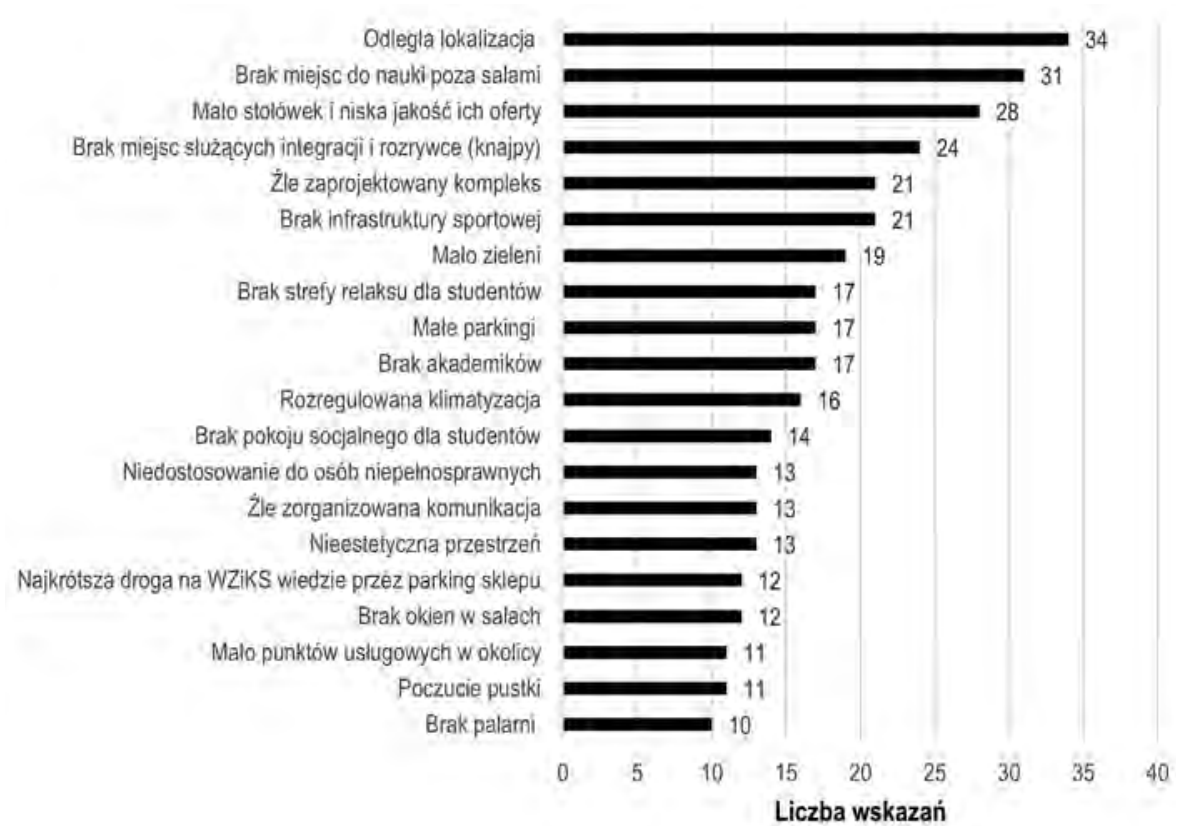

Ryc. 2. Słabe strony Kampusu UJ i budynku WZiKS

Fig. 2. Weaknesses of the JU Campus and the FoMaSK building w szczególności większych drzew, są natomiast duże place wyłożone kostką brukową. Zwrócono również uwagę na zbyt małe parkingi (szczególnie w trakcie zjazdów na studiach niestacjonarnych) oraz brak akademików na terenie Kampusu. Zdaniem części grup komunikacja jest słabo rozwinięta - studenci wskazywali szczególnie na małą liczbę połączeń w weekendy oraz na korki tworzące się na drogach dojazdowych do Kampusu. Pisano także o nieestetycznej przestrzeni - braku spójności poszczególnych budynków i „szpitalnych”, szarych wnętrzach poszczególnych wydziałów. Na Kampusie brakuje także punktów usługowych - sklepów, kawiarni, bankomatów czy przedszkoli. Przestrzeń, zdaniem niektórych, stwarza poczucie pustki - życie skoncentrowane jest raczej wewnątrz budynków, dużo przestrzeni nie zostało jeszcze zagospodarowanych.

W przeciwieństwie do innych części analizy SWOT w przypadku słabych stron duża liczba wskazań dotyczyła samego budynku WZiKS. Studentom łatwiej było odnieść się do konkretnych wad przestrzeni, którą użytkują na co dzień. Wskazywali, że na korytarzach jest zbyt mało miejsc do wspólnej nauki (ławki, krzesła stoły, przy których można pracować w grupach) oraz „stref relaksu” ze stolikami i pufami. Klimatyzacja w salach jest rozregulowana - w jednych zbyt zimno, w drugich gorąco. Brakuje też pokoi socjalnych dla studentów z czajnikiem i mikrofalą, w których mogliby zrobić sobie herbatę lub odgrzać własne posiłki. Sam budynek nie jest w pełni dostosowany do potrzeb osób z niepełnosprawnościami: brak podjazdów w salach wykładowych, a na zewnątrz budynku znajdują się wysokie chodniki. Jako słabą stronę wskazano także brak bezpośredniego dojścia do budynku - najbliższy przystanek komunikacji miejskiej usytuowany jest w taki sposób, że najkrótsza droga na Kampus wiedzie przez ruchliwy parking sklepu wielkopowierzchniowego; po jego przejściu studenci wchodzą do budynku bocznym wejściem. Na wydziale brakuje okien w salach i korytarzach, przez co światło słoneczne nie ma do nich dostępu, trudno też je przewietrzyć. Ostatnia ze zidentyfikowanych słabych stron wiąże się z brakiem palarni - w związku z tym palacze gromadzą się właśnie przed bocznym wejściem do budynku, co jest mało komfortowe dla samych palących i osób, które próbują dostać się do budynku, ponieważ muszą przejść przez chmurę tytoniowego dymu.

\section{Szanse dla III Kampusu UJ i budynku WZiKS}

Zidentyfikowane szanse odnosiły się do całego III Kampusu UJ (ryc. 3). Największą z nich studenci widzieli w rozbudowie Kampusu - wolna przestrzeń daje możliwośc powstania nowych obiektów oraz przygotowywania wydarzeń (m.in. konferencji czy imprez kulturalnych organizowanych przez studentów). Szansę dostrzegano także w tym, iż przestrzeń kampusu jest atrakcyjna i przyjazna, dobrze spędza się w niej czas i można się w niej odprężyć, co w zestawieniu z ofertą studiów może sprawić, 


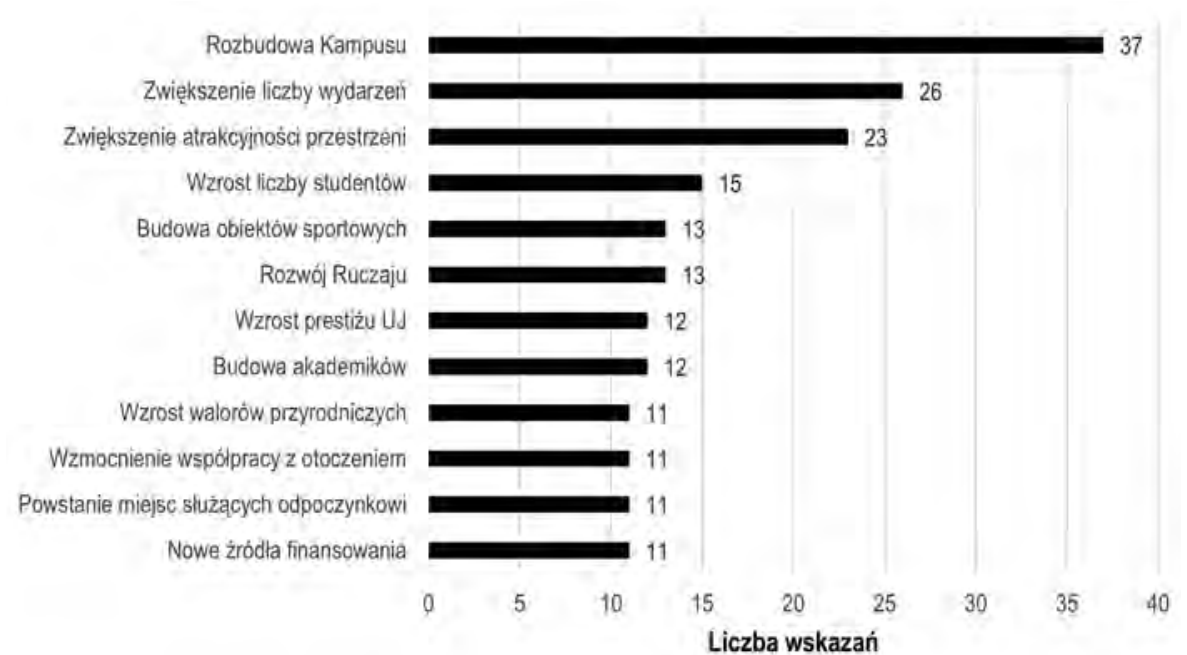

Ryc. 3. Szanse dla Kampusu UJ i budynku WZiKS

Fig. 3. Opportunities for the JU Campus and the FoMaSK building

że zwiększy się liczba studentów. Możliwości rozwojowych studenci upatrywali także w budowie obiektów sportowych, takich jak basen, siłownia, hala sportowa, oraz akademików. Wśród perspektyw na przyszłość wymieniano także rozwój Ruczaju powstanie nowych mieszkań, punktów handlowo-usługowych, korporacji czy pojawienie się innych inwestycji. Ważny jest także wzrost prestiżu Uniwersytetu - zyskanie przewagi konkurencyjnej nad pozostałymi krajowymi uczelniami, umiędzynarodowienie czy posiadanie nowoczesnego Kampusu może wpływać na wizerunek UJ jako miejsca innowacyjnego i atrakcyjnego dla studentów. W dalszej perspektywie ważne może być też wzmocnienie współpracy z otoczeniem (m.in. pobliskim Krakowskim Parkiem Technologicznym, a także innymi uczelniami) oraz pojawienie się nowych źródeł finansowania inwestycji, w tym środków pochodzących z funduszy europejskich. Szanse widziano również we wzroście walorów przyrodniczych obszaru (m.in. w zagospodarowaniu Zakrzówka, nowych nasadzeniach, skwerach), powstaniu miejsc służących odpoczynkowi czy otwarciu punktów gastronomicznych. Potencjalnie ważny mógł być także rozwój komunikacji publicznej i budowa Trasy Łagiewnickiej. Ponadto zwracano uwagę na szansę związaną ze wzmocnieniem współpracy między wydziałami znajdującymi się na Kampusie i większym dostosowaniem poszczególnych budynków do potrzeb osób z niepełnosprawnościami. Ważne mogłoby być też wykorzystanie kapitału studentów i pracowników - generowanie nowych pomysłów, które mogłyby ulepszyć tę przestrzeń.

\section{Zagrożenie dla Kampusu UJ i budynku WZiKS}

Pierwszym ze zidentyfikowanych zagrożeń (ryc. 4) był brak zainteresowania ze strony przyszłych studentów: ze względu na odległość Kampusu UJ od centrum, mało atrakcyjną ofertę edukacyjną lub inne przyczyny zewnętrzne studenci mog nie być zainteresowani podjęciem tam studiów. Duże zagrożenie może stanowić także wzrastająca konkurencja ze strony innych uniwersytetów. Niebezpieczeństwo w oczach studentów stanowiły też duże koszty utrzymania budynków przy jednoczesnym zmniejszeniu finansowania i braku możliwości zdobycia dodatkowych środków. Negatywne oddziaływanie na III Kampus UJ mogłaby też mieć rozbudowa okolicznych osiedli oraz jego samego kosztem zieleni. Zagrożenie może też stanowić pogarszająca się sieć połączeń komunikacji miejskiej, przedłużająca się budowa Trasy Łagiewnickiej oraz korki na drogach dojazdowych. Wśród zagrożeń, które uzyskały mniejszą liczbę wskazań, wymieniano te związane z demografią, gdyż mog niekorzystnie wpłynąć na rozwój III Kampusu - niż demograficzny może skutkować zmniejszeniem liczby kandydatów i przychodów Uczelni. Zagrożeniem może też być spadek poczucia bezpieczeństwa (wypadki na drogach wewnętrznych, problemy z ewakuacją czy pandemia). Studenci zwracali także uwagę na wzrost cen mieszkań, usług i czynszu za studia, co w konsekwencji może sprawić, że nie każdego będzie stać na studia. Kolejną kwestią było „upublicznienie” się przestrzeni - jest ona otwarta dla wszystkich i stanowi oazę zieleni w mocno zabudowanej okolicy, przez co - zdaniem studentów - może być „przejęta” przez mieszkańców pobliskich osiedli i szybciej się zużywać, może też być niszczona (zarówno przez studentów, jak i mieszkańców). Wskazywano także, iż wzrost samowystarczalności Kampusu (powstanie obiektów sportowych, punktów usługowych, akademików) może pogłębic

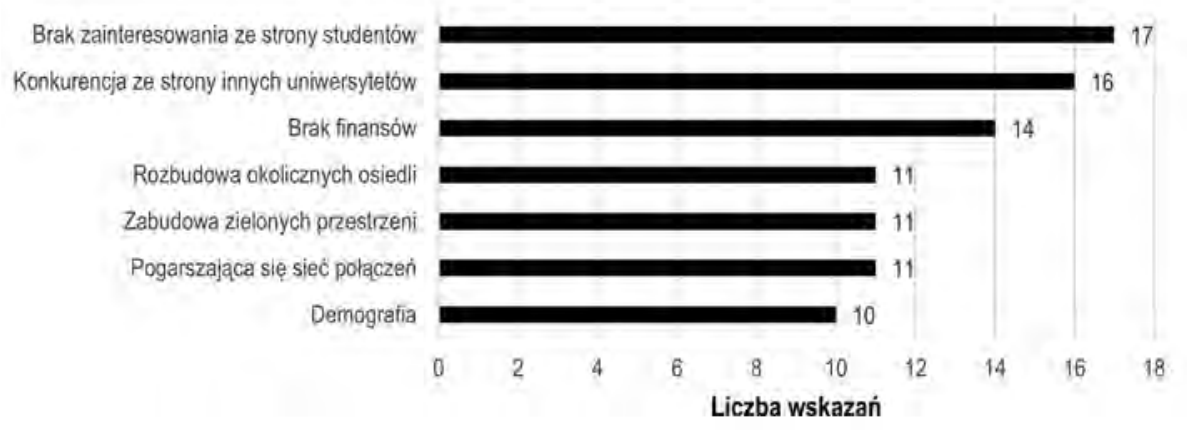

Ryc. 4. Zagrożenia dla Kampusu UJ i budynku WZiKS

Fig. 4. Threats to the JU Campus and the FoMaSK building 
jego izolację - może on stać się „,miastem w mieście”, odseparowanym od otoczenia. Zagrożenie mogą stanowić również negatywne zmiany ustawodawcze, wstrzymanie rozbudowy Kampusu lub jej nadmierna intensyfikacja oraz wpływ warunków naturalnych, takich jak powodzie, susze czy wichury.

\section{Odbiorcy przestrzeni Kampusu UJ i budynku WZiKS}

Zadaniem studentów była także identyfikacja odbiorców przestrzeni III Kampusu UJ (ryc. 5). Wszyscy wskazali, że powinna to być przestrzeń przede wszystkim dla studentów. Blisko $40 \%$ grup wyróżniło zarówno samych wykładowców, jak i pracowników Uniwersytetu Jagiellońskiego w ogóle (np. pracowników administracji) Istotnym odbiorcą przestrzeni są też mieszkańcy okolicznych osiedli. Wśród innych grup odbiorców znaleźli się m.in.: przedsiębiorcy, pracodawcy, kandydaci na studia i absolwenci, rodziny z dziećmi, osoby starsze i z niepełnosprawnościami, rowerzyści, biegacze czy turyści. Ogólnie studenci swoimi odpowiedziami wskazywali, że Kampus UJ nie ma być jedynie zamkniętą enklawą, służącą tylko celom studentów społeczności akademickiej, lecz przestrzenią dostępną, inkluzyjną i przyjazną dla wszystkich.

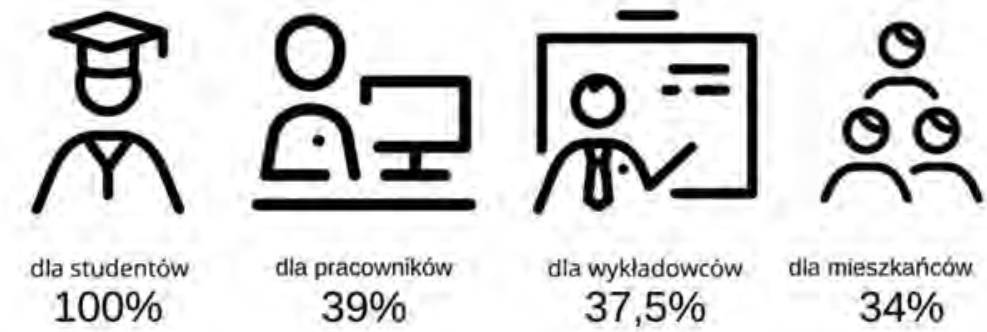

Ryc. 5. Dla kogo powinna być przestrzeń Kampusu UJ?

Fig. 5. Who should be the target group for the space of the JU Campus?

Źródto: opracowanie własne na podstawie badań; ikony stworzone przez Freepik ze strony www.flaticon.com.

Source: based on own research. Icon made by Freepik from www.flaticon.com.

Propozycje inwestycji w przestrzeni Kampusu UJ i w budynku WZiKS

Kolejnym zadaniem studentów było wskazanie propozycji działań, które można zrealizować małym nakładem środków w krótkiej perspektywie czasowej (ryc. 6).

Na pierwszym miejscu znalazło się stworzenie zewnętrznej strefy relaksu - na taką potrzebę wskazało ponad 70\% grup. Mogłyby się w niej znaleźć ławki i stoliki, leżaki, hamaki, parasole, altany, ogródek letni, a nawet huśtawki czy koce do rozłożenia na trawie. Dużą liczbę wskazań zyskało zwiększenie ilości zieleni na Kampusie, w tym nowe nasadzenia drzew, krzewów i kwiatów, stworzenie ogródka społecznego dla studentów z miejscami piknikowymi czy wstawienie większej liczby kwietników wewnątrz budynków. Studenci proponowali także stworzenie strefy relaksu wewnątrz budynków (z pufami, grami wideo i planszowymi oraz stołem do ping-ponga) oraz ustawienie dodatkowych ławek i stołów wewnątrz budynków, które mogłyby służyć do pracy indywidualnej oraz grupowej (miejsca do nauki jako osobną kategorię wyróżniło dodatkowo 16 grup). Kolejnym z pomysłów była organizacja większej liczby wydarzeń, np. koncertów, kina plenerowego, wieczorów poezji, imprez sportowych, gier miejskich, jam session, Juwenaliów, a nawet zajęć plenerowych. Inną spośród idei był wynajem placów pod działalność foodtrucków, wózków z napojami, lodami, kawą - wskazało na nią aż 19 grup. Zdaniem studentów warto również rozszerzyć ofertę gastronomiczną przez powstanie nowych punktów i zwiększenie ich asortymentu. Zwracali oni również uwagę na koniecznośc uzupełnienia wyposażenia budynku, np. o zegary w salach, dodatkowe kosze na śmieci z możliwością segregacji, szafki, w których można bezpiecznie zostawic rzeczy, czy automaty ze zdrową żywnością. Dobrym pomysłem może być także stworzenie miejsc do uprawiania różnego rodzaju sportów, w tym zakup trampolin,

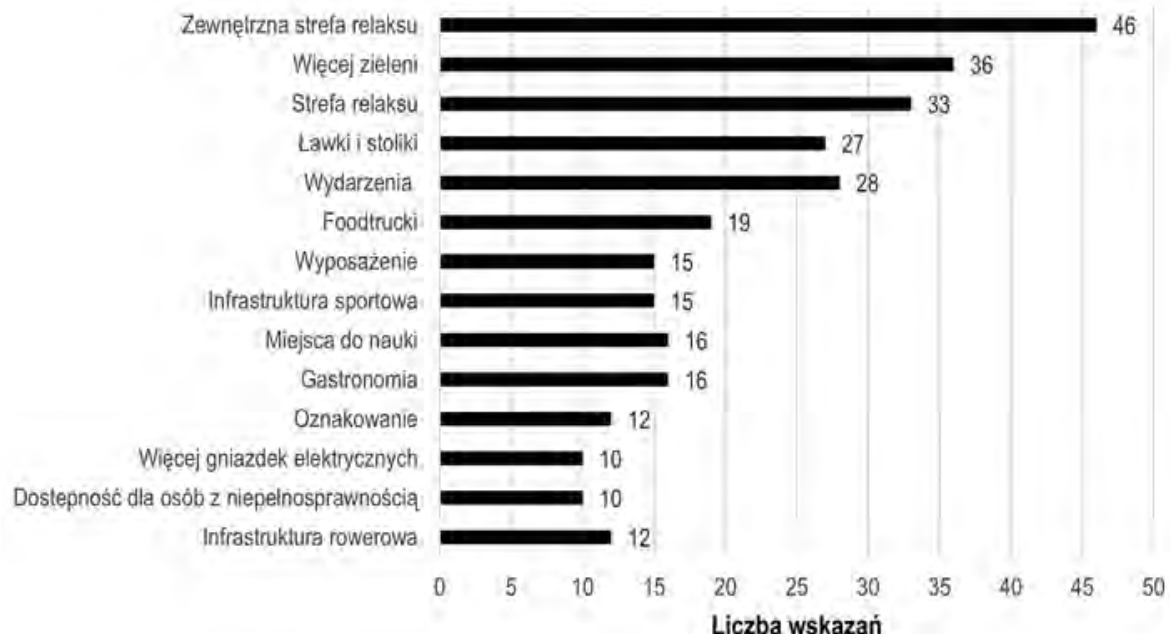

Ryc. 6. Małe inwestycje na Kampusie UJ i w budynku WZiKS

Fig 6. Small Investments on the JU Campus and the FoMaSK building 
stołów do ping-ponga, miejsc do grania w szachy czy uprawiania jogi. Należy rów nież w lepszy sposób oznakować przestrzeń Kampusu i wnętrza poszczególnych budynków: stworzyć mapę III Kampusu, strzałki kierunkowe czy dodać tablice z ciekawostkami dotyczącymi historii uczelni oraz zorganizować konkurs wśród studentów kierunków artystycznych na system informacji wizualnej. Taka samą liczbę wskazań zyskał pomysł dotyczący rozbudowy infrastruktury rowerowej (parkingi, wypożyczalnie, inne udogodnienia). Studenci wskazywali również na potrzebę instalacji większej liczby gniazdek elektrycznych, by móc podładować w nich baterię w telefonie czy laptopie. Istotne było także dostosowanie Kampusu i poszczególnych budynków do potrzeb osób z niepełnosprawnościami. Wśród innych pomysłów znalazło się wprowadzenie rozwiązań ekologicznych (np. wycofanie plastikowych sztućców i kubków), wzmocnienie sygnału wi-fi, stworzenie pokoju socjalnego czy palarni.

Wśród działań, na które potrzeba więcej środków finansowych i można je zrealizować w dłuższej perspektywie czasowej (ryc. 7), studenci na pierwszym miejscu wskazali powstanie kompleksu sportowego, w którym mogłyby się znajdować hala, korty tenisowe, przestrzeń do gry w minigolfa, „Orlik”, stadion, siłownia zewnętrzne stoły do gry w piłkarzyki i ping-ponga czy boisko do gry w piłkę plażową. Dodatkowo 12 grup wyszczególniło budowę pływalni (krytej lub odkrytej). Dużą liczbę głosów zdobyły także akademiki. Studenci widzą konieczność budowy na Kampusie knajp, restauracji, kawiarni czy klubów, w których mieliby szansę się zintegrować. Ważnym postulatem była również budowa punktów handlowo-usługowych, w szczególności sklepów, a także przychodni zdrowia. Zwracano też uwagę na konieczność przebudowy dojścia do WZiKS oraz powstania nowych ścieżek rowerowych i biegowych. Tyle samo wskazań zdobyła budowa dodatkowych parkingów. Wśród pomysłów, które zdobyły mniejszą liczbę wskazań, znalazły

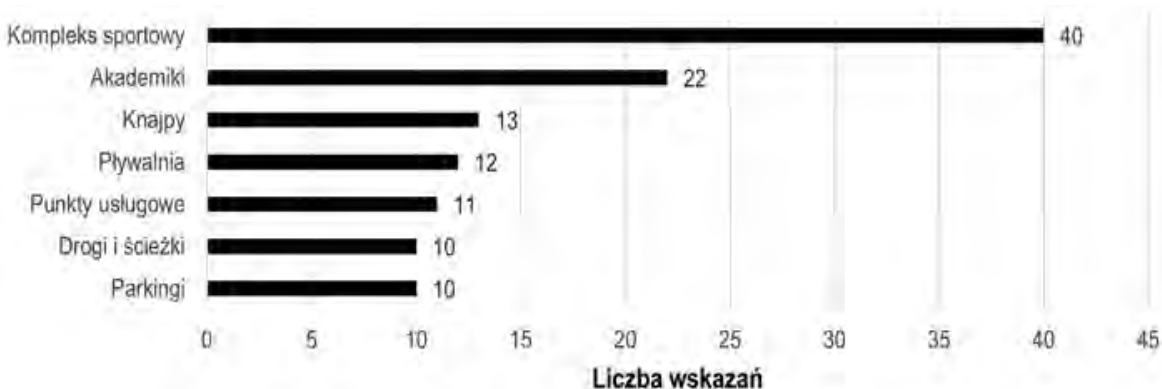

Ryc. 7. Duże inwestycje na Kampusie UJ i w budynku WZiKS

Fig. 7. Large Investments on the JU Campus and the FoMaSK building się: zewnętrzny amfiteatr, sala kinowa i widowiskowa, przedszkole, park, ogrody na dachach, specjalna linia autobusowa tylko dla studentów, a nawet wewnętrzna kolejka elektryczna na terenie Kampusu.

\section{Studia przypadków}

W dalszej części artykułu wskazano na przykłady działań podejmowanych na Kampusach uniwersyteckich. Są one powiązane z przedstawioną powyżej oceną przestrzeni III Kampusu UJ zarówno w zakresie mocnych stron i szans, jak i słabych stron oraz zagrożeń. Uwidoczniają także, iż proponowane przez studentów działania są możliwe do realizacji.

\section{Festiwal Kultury i Mediów „Polikultura”}

Festiwal Kultury i Mediów „Polikultura” organizowany jest od 2013 r. przez studentów I roku studiów licencjackich na kierunku Zarządzanie kulturą i mediam w Instytucie Kultury Uniwersytetu Jagiellońskiego. Studenci pod kierunkiem pracowników, doktorantów i współpracowników Instytutu w kilkuosobowych grupach przez cały rok pracują nad organizacją własnych projektów kulturalnych i medialnych, które mają się odbyć w trakcie majowego festiwalu (Konior, Pluszyńska 2018). Sami studenci opisywali Festiwal w taki sposób: „,...] Festiwal, oprócz misji artystycznej i społecznej, pełni również funkcję edukacyjną. Przygotowuje studentów do zawodów menedżerów kultury i mediów. 110 młodych organizatorów, działających w 10 grupach przez cały rok akademicki, intensywnie pracowało nad swoimi projektami. Szukanie sponsorów i zbieranie funduszy to tylko namiastka wyzwań, przed którymi stanęli studenci podczas organizacji Polikultury. Nie można jednak zapomnieć o ich pracy zespołowej, bez której festiwal by nie zaistniał, a której wielką siłę ukazały akcja pozyskiwania funduszy na PolakPotrafi.pl oraz zbieranie głosów w konkursie na Studencki Projekt Roku. Wszyscy zaangażowan w festiwal niewątpliwie włożyli w niego całe serce i poświęcili mu wiele energii. Nieprzespane noce, litry kawy. Uśmiechy radości, łzy bezsilności. Właśnie o tych osobach jest ta publikacja - są dowodem na to, że istnieją na świecie ludzie, którzy walczą mimo wszelkich przeciwności i których działania przynoszą niesamowite efekty (Lisik, Zegan 2016)".

Festiwal odbywa się w różnych lokalizacjach w Krakowie. Pierwsza edycja została zorganizowana w Centrum Kultury Rotunda, kolejne odbyły się w poprzemysłowe dzielnicy Zabłocie, w hotelu Cracovia, klubie Żaczek czy Collegium Maius. W 2015 r. podczas trzeciej edycji festiwalu, studenci zorganizowali kilka wydarzeń, których celem było ożywienie przestrzeni Kampusu 600-lecia Odnowienia UJ 
W 2015 r. w ramach podjętych działań na II piętrze budynku WZiKS, przed wejściem do sekretariatu Instytutu Kultury powstał mural autorstwa Sebastiana Bożka, przedstawiający Helenę Modrzejewską, wybitną polską aktorkę. Badaczem jej biografii i twórczości jest założyciel IK, prof. Emil Orzechowski. Odsłonięcie muralu zbiegło się z zainicjowaniem działalności galerii plakatu z kolekcji Krzysztofa Dydo. Studenci sami wybrali plakaty, które miały zawisnąć w korytarzu Instytutu Kultury. Ponadto wspólnie z pracownikami i koordynatorami pomalowali ściany przyszłe galerii na kolor wcześniej wyłoniony w głosowaniu wśród pracowników IK UJ. Wernisaż wystawy i odsłonięcie muralu nastąpiły 22 maja 2015 r. przy udziale pracowników oraz studentów Instytutu Kultury (Otwarcie Galerii Plakatu...). Dotąd wystawa plakatów była zmieniana dwukrotnie: w 2016 r. w ramach IV edycji „Polikultury” i w 2019 r. w trakcie 7th Humanistic Management Conference, za każdym razem przy pełnym zaangażowaniu studentów.

Na finał trzeciej edycji festiwalu zorganizowano pokaz mody, który odbył się przed wejściem do budynku Wydziału Zarządzania i Komunikacji Społecznej Uniwersytetu Jagiellońskiego (fot. 1). Na wybiegu zaprezentowano kreacje młodych projektantów: Michała Wójciaka, Agnieszki Byczkowskiej, Agnieszki Unzeitig, Beaty Koniakowskiej, Agaty Tomo Lechety, Marianny Król oraz Joanny Maligłówki. Po pokazie można było zakupić prezentowane ubrania. Pokaz był współorganizowan z innymi podmiotami edukacyjnymi: Szkołą Artystycznego Projektowania Ubioru oraz Szkołą Wizażu i Stylizacji „Artystyczna Alternatywa” (Zabłocie Inspirujqce...).

Warto również dodać, że od paru lat festiwal nie ogranicza się do kilku majowych dni, ale od października do końca kwietnia studenci organizują liczne wydarzenia fundraisingowe, które mają na celu zgromadzenie funduszy na jego realizację. Część z nich odbywa się na terenie budynku WZiKS. Do tej pory na Kampusie zorganizowano kilkadziesiąt wydarzeń, w tym: kiermasze (świąteczne, książek, ciast), swapy wymiany ubrań i akcesoriów - wykłady, warsztaty, slajdowiska, seanse filmowe z prelekcjami czy wspólne granie w gry planszowe i retro gry komputerowe. Jedną z ciekawszych aktywności była też licytacja, którą w pierwszej edycji nazwano POLIcytUJ, a w kolejnej Skarby Profesorów. Licytowano wówczas przedmioty przekazane przez pracowników naukowo-dydaktycznych Wydziału Zarządzania i Komunikacji Społecznej; do każdego z nich był dołączony krótki opis z historią przedmiotu (Polikultura).

\section{„Ogrody kampusowe” Fachhochschule Potsdam}

$\mathrm{Na}$ fali rozwijającego się ogrodnictwa miejskiego (urban gardening) również na terenach kampusów coraz częściej podejmowane są inicjatywy związane z ogrodnictwem. Za przykład dobrej praktyki może służyć projekt Campusgarten („Ogród kampusowy") realizowany na terenie Fachhochschule w Poczdamie. Ogród nazy-

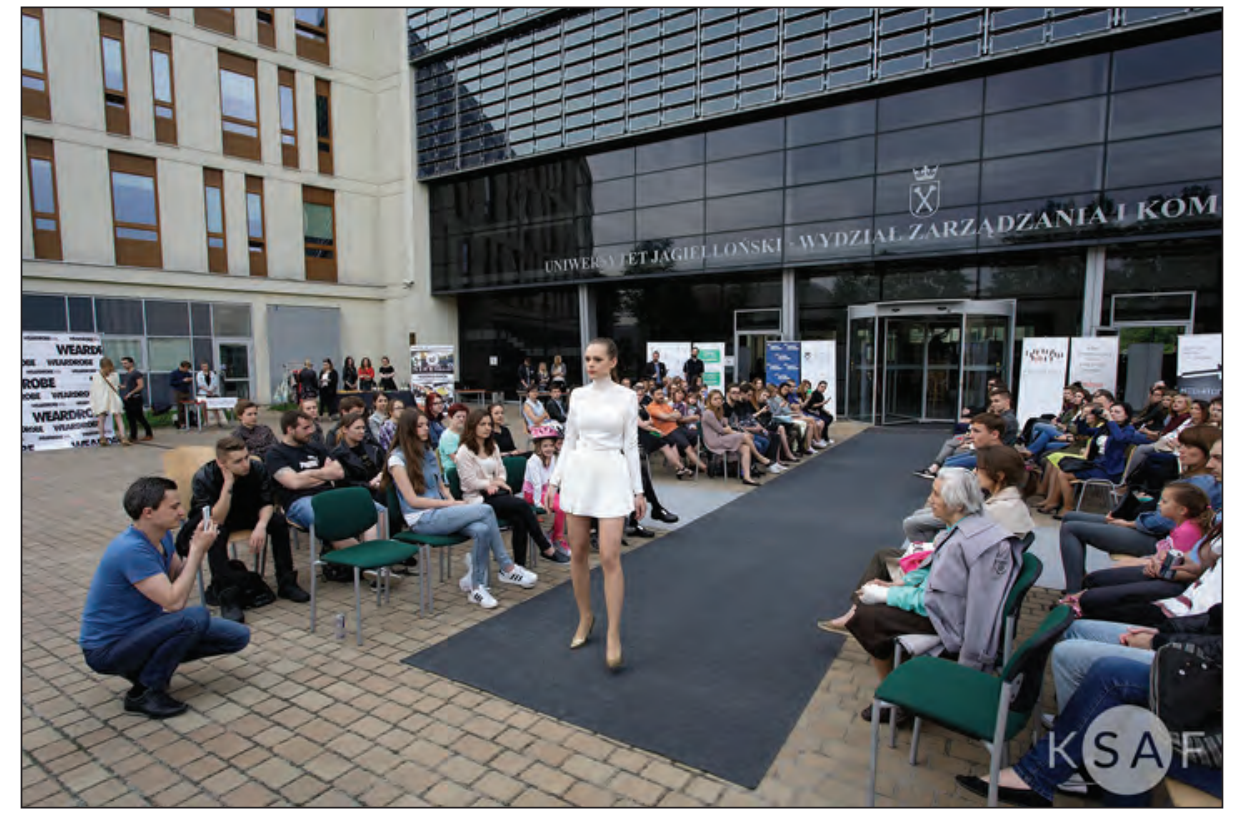

Fot. 1. Pokaz mody przed budynkiem Wydziału Zarządzania i Komunikacji Społecznej w ramach trzeciej edycji Festiwalu Kultury i Mediów „Polikultura”

Photo 1. Fashion show in front of the building of the Faculty of Management and Social Communication as part of the third edition of the „Polikultura”-Culture and Media Festival Źródto: www.facebook.com/polikulturafest/photos/a.393071490885335/393073380885146/ Source: www.facebook.com/polikulturafest/photos/a.393071490885335/393073380885146/

wany jest „społeczną przestrzenią interakcji i eksperymentu” (Campusgarten FH Potsdam).

Pomysł na stworzenie ogrodu na terenie uczelni powstał z inicjatywy studentów oraz mieszkańców dzielnicy Bornstedt. Studenci, realizujący projekt w ramach seminarium, stworzyli koncepcję, która obejmowała m.in. działania zachęcające do partycypacji różnych odbiorców przestrzeni z uwzględnieniem ich potrzeb. W zamyśle ogród ma być miejscem powszechnie dostępnym i otwartym zarówno dla całej społeczności akademickiej, jak i właśnie mieszkańców. Jest to o tyle ciekawe, że zachęca się tym samym mieszkańców okolicznych osiedli do korzystania z przestrzeni i terenów zielonych między wydziałami. Kampus przestaje być wówczas odgrodzonym terenem, a staje się częścią tkanki miejskiej, z którą mają styczność także osoby niezwiązane z uczelnią. Widać to szczególnie „po godzinach”, gdy np. ze skwerów i ławek chętnie korzystają rodziny z dziećmi czy seniorzy. Ze względu na słabą jakość ziemi i ryzyko, 
że może być zanieczyszczona, zdecydowano się na podwyższone grządki, w których nasadzono zarówno rośliny ozdobne, jak i warzywa oraz zioła. Ponadto ustawiono kompostownik i hotel dla owadów, a także miejsca do siedzenia. Oprócz wyznaczonej grupy projektowej ogrodem zajmują się również wolontariusze.

Ogród nie jest jedyna przestrzenia na poczdamskim kampusie de facto zarządzaną przez studentów. Znajduje się tam również knajpa Casino, którą prowadzą studenci już od ponad 25 lat. W ciągu roku akademickiego jest otwarta w godzinach 10-24 natomiast w czasie przerw semestralnych tylko wieczorami w niektóre dni. Lokal służy za miejsce spotkań w ciągu dnia, a także gości koncerty czy inne wydarzenia kulturalne. Oferta lokalu jest bardzo przystępna cenowo. $Z$ perspektywy polskiego studenta może zadziwiać sprzedaż alkoholu na terenie należącym do uczelni, jednak miejsce to ma służyć przede wszystkim integracji. Jak podkreślone jest na stronie lokalu, wszelkie imprezy odbywające się w Casino muszą przynosić jakąś korzyść całej społecznośc studenckiej, więc nie ma możliwości organizacji prywatnych wydarzeń (Casino).

\section{Kompleksowy kampus - Radboud University Nijmegen, Holandia}

Kampus holenderskiego uniwersytetu w Nijmegen jest w dużym stopniu jednostką autonomiczną, choć otwartą na miasto, o powierzchni ok. 100 ha. Na jego terenie można dostrzec wiele działań, które stopniowo wdrażane, wciąż dostosowują przestrzeń do zmieniających się potrzeb i warunków.

W połowie lat $90 . \mathrm{XX}$ w. zadecydowano o konieczności zapewnienia większej spójności między budynkami a otaczającymi je terenami zielonymi. Nowe budynki stały się kompaktowe - by nie zajmowały niepotrzebnie dużo powierzchni - duża częśc parkingów została zaś umieszczona pod ziemią, co zredukowało te na powierzchn o blisko 50\%. Uzyskano dzięki temu wiele terenów zielonych oraz dobrze rozplanowane ciągi piesze i ścieżki rowerowe. $Z$ kolei nowe inwestycje muszą spełniac wysokie standardy zrównoważonego rozwoju (Green Campus).

Jeśli chodzi o usługi i inne udogodnienia typowe dla kampusów, to sięgają one od punktów poligraficznych przez stołówki, sklepy (w tym market), po infrastrukturę sportową. Do dyspozycji studentów jest centrum rekreacyjne, w którym można uprawiać 70 różnych dyscyplin (w tym: zumbę, pole dancing, wspinaczkę, boks, tenis). Ponadto na terenie uczelni działa biuro „Radboud Green Office” wspierające osiągnięcie celu, jakim jest stuprocentowo zrównoważony kampus.

\section{Podsumowanie}

Choć przestrzenie III Kampusu i WZiKS wciąż ulegają zmianom, to sugestie studentów są dość jasnym komunikatem, czego wciąż brakuje. Brak np. przestrzeni wypoczynkowych czy do pracy w grupach jest dużym problemem, który ewidentnie nie był brany pod uwage w czasie projektowania budynków. Wydaje się jednak dość proste utworzenie tymczasowych czy zastępczych miejsc służących tym celom. Interesującą kwestią jest też z pozoru błahy problem, polegający na niewystarczającej liczbie gniazdek elektrycznych - w momencie budowy WZiKS studenci nie dysponowali jeszcze taką ilością sprzętu elektronicznego, który wymagałby ciągłego ładowania. Jednakże ta kwestia doskonale obrazuje fakt, że przestrzeń trzeba nieustannie dostosowywać do zmieniającej się rzeczywistości i potrzeb jej odbiorców. Wśród przytaczanych przez Ağlargöz (2016) cytatów z jego badań nad kampusami pada określenie kampusu „aspołecznego”: trudno dostępnego, bez życia, gdzie nikt nie spędza czasu poza obowiązkowymi godzinami pracy czy nauki. Taka przestrzeń nie sprzyja rozwojowi, kreatywności, postępowi, nie buduje się w niej zdrowa kultura organizacyjna, społeczność akademicka nie tworzy energicznej wspólnoty.

Analiza wyników prac studenckich wykazała jeszcze jedno ciekawe zjawisko: wiele aspektów funkcjonowania III Kampusu i budynku WZiKS jest postrzeganych jednocześnie jako mocna i słaba strona, w zależności na co kładziony jest akcent. Dla przykładu: z jednej strony doceniana jest dostępność komunikacyjna z punktu widzenia sieci tramwajowej i bliskości autostrady, a z drugiej - odległość od miasta i peryferyjność kampusu krytykowana.

Przytoczone studia przypadków pokazują realizacje, które uwzględniają potrzeby zasygnalizowane przez studentów, np. potrzebę integracji, zieleni, przestrzeni do wypoczynku czy rozrywki, wobec czego mogą stanowić punkty odniesienia dla decydentów w sprawie dalszego rozwoju kampusu i jego funkcjonowania w otoczeniu.

Sensownym krokiem zdaje się również włączanie w większym stopniu studentów w kształtowanie przestrzeni, w której spędzają jednak dużo czasu i za którą mogliby przejąć pewną odpowiedzialność. Choć w czasie „Polikultury” podejmowane są takie działania, to poczdamskie projekty pokazują, jak niewielki może być obsza autonomii dla studentów, a jak wiele zmieniać w percepcji danego miejsca. Z kole przykład kampusu w Nijmegen pokazuje, jak rozwijają się ośrodki akademickie zgodnie z koncepcją zrównoważonego rozwoju.

\section{Literatura}

Ağlargöz O., 2016, 'We are at this campus, there is nothing in this campus...': Socio-spatial analysi. of a university campus, Tertiary Education and Management, 23 (1), 69-83.

Boryczka E.M., Sokołowicz M.E., Wróblewski W., Zasina J., 2012, Poradnik dla uczestnikóre Warsztatów po kolei czas na Łódź, Studenckie Koło Naukowe Gospodarki Przestrzenne Uniwersytetu Łódzkiego SPATIUM, Łódź.

Campusgarten FH Potsdam, www.campusgarten-potsdam.de/campusgarten (dostęp: 18.06.2020). 
Cannas da Silva L., Valsassina Heitor T., 2017, Campuses as Sustainable Urban Engines A Morphological Approach to Campus Social Sustainability, [w:] W. Leal Filho et al. (eds.), Handbook of Theory and Practice of Sustainable Development in Higher Education, World Sustainability Series, Springer, 259-276.

Casino FHP, https://casino-fhp.de/ (dostęp: 18.06.2020).

Green Campus, www.ru.nl/propertymanagement/building-on-campus/green-campus/ (dostęp: 18.06.2020).

Jak præetworzyć miejsce? Poradnik kreowania udanych præestræeni publicznych, 2012, Fundacja Partnerstwo dla Środowiska, Kraków.

Konior A., Pluszyńska A., 2018, Festiwal Kultury i Mediów „Polikultura” jako przyktad kampanii crowdfundingowej w kulturze, [w:] A. Pluszyńska, A. Szopa (red.), Crowdfunding w Polsce, Wydawnictwo Uniwersytetu Jagiellońskiego, Kraków.

Koźmiński A.K., Piotrowski W., 2006, Zarzqdzanie. Teoria i praktyka, Wydawnictwo Naukowe PWN, Warszawa.

Lisik B., Zegan J., 2016, Polikultura: Lubię kiedy nocq..., [w:] J. Zegan, Lubię kiedy nocq... Publikacja IV edycji Polikultury, Instytut Kultury UJ, Kraków.

Mazur B., 2014, Kultura organizacyjna w perspektywie poznawczej. Próba operacjonalizacji, [w:] Ł. Sułkowski, C. Sikorski (red.), Metody zaræqdzania kulturq organizacyjnq, Difin, Warszawa.

Otwarcie Galerii Plakatu Kulturalnego Dydo i prezentacja muralu Sebastiana Bożka I Inauguracja Festiwalu na Kampusie UJ I Polikultura, www.facebook.com/events/1440175556276341/ (dostęp: 3.06.2020).

Polikultura, www.facebook.com/polikulturafest/ (dostęp: 04.06.2020).

Powstanie Kampusu. Krok po kroku, www.uj.edu.pl/kampus/historia-budowy (dostęp: 10.06.2020).

Rytkönen E., 2014, Community-Focused Perspectives to Interdisciplinary University Campus Management - A Buisiness Model Case Study, 20th Annual Pacific-Rim Real Estate Society Conference, Christchurch, New Zealand, 19-22 January 2014.

Rymarzak M., 2014, University space management exemplified by selected European entities, Real Estate Management and Valuation, 22-29.

Rymarzak M., 2016, Uwarunkowania «aræqdzania nieruchomościami publičnych uniwersytetów na przykładzie wybranych krajow UE, Horyzonty Wychowania, 15 (35), 233-246.

Zabtocie Inspirujace - pokaz mody | Oficjalne zakończenie Festiwalu Kultury i Mediów „Polikultura” 2015, www.facebook.com/events/1074087709273194 (dostęp: 03.06.2020).

Agnieszka Konior (ORCID: 0000-0003-2338-6594)

Weronika Pokojska (ORCID: 0000-0001-8734-9595)

Uniwersytet Jagiellonski

Wydziat Zarzqdzania i Komunikacji Spotecznej

Instytut Kultury

ul. Łojasiewic: a 4, 30-348 Kraków

agn.konior@uj.edu.pl,weronika.pokojska@uj.edu.pl 